\title{
皿ばねの非線形変形挙動について* \\ On Nonlinear Deformation Behavior of Disk Spring
}

濱田 實**・荒木 敏弘***

\author{
Minoru HAMADA - Toshihiro ARAKI
}

皿ばねが圧縮荷重を受ける場合に示す非線形の荷重一たわみ線図については，従来よりJ.O. Almen \& A.Laszlo1)の式が広く用いられてきた。これに対して，より精度の高い式として G.A. Wempner ${ }^{2)}$ の式が提案されているが, これら二つの式は，いずれも近似的仮定のもとに導かれ たものであるから，これらの式がどの程度の䛊差を含むかについて，皿ばねを使用する機械設 計者はよく知っていなければならない。本研究では，皿ばねに対し弾性薄殼理論を適用して得 られる支配微分方程式を差分法 ${ }^{3}$ により数值的に解いて, 精度の高い荷重一たわみ関係の解をい くつか求める。一方, 上記の二つの近似式により対応する解を求め, これら三つの解を比較す る。また，いくつかの場合に対して実験を行い，その結果も比較に供する。そして，これらの 比較の結果を総合的に見て, 二つの近似式の精度に関していくつかの知見を得る。

For estimation of the nonlinear load-deflection behavior of the disk spring which is subjected to compressive load, an approximate equation presented by J.O. Almen \& A. Laszlo ${ }^{1)}$ has widely been used. Another approximate equation was also proposed by G.A. Wempner ${ }^{2)}$ as a more accurate solution. Since these two equations are both induced from some aproximate assumptions, mechanical designers using disk springs should know the degree of errors of the above-mentioned two equations. In this paper, some numerically accurate examples for the load-deflection relation of the disk spring are obtained by applying the finite difference method ${ }^{3}$ to solve the fundamental differential equations of the problem of the disk spring, and they are compared with the results obtained by the above-mentioned two equations. Also experiments are carried out, and their results are compared with those by the above three theoretical methods. From results of such comparisons some prospect about the accuracy of the above-mentioned two equations can be obtained.

\section{1. まえがき}

皿ばねは，その占める空間が許容荷重に対して小さ く設定できることと，変形特性の非線形性が，場合に よっては非常にうまく利用できることのために，現在 各方面で広く用いられている。亚ばねの変形特性すな わち荷重一たわみ線図については，J.O. Almen \& A

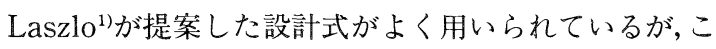
の式にはいくつかの近似の仮定が含まれているため, その精度についてはつねに注意を払わなければならな い.この Almen-Laszloの式よりも精度の高い式とし て G.A. Wempner ${ }^{2)}$ 式があるが, この式も近似式であ ることには変りがない。これらに対して, 最も精度の 高い皿ばねの解は, 弾性殼理論による皿ばね問題の支 配微分方程式を, 差分法や有限要素法などの数值解法

原稿受付日 1990 年 9 月 7 日

* ばね技術研究会 1990年度春期講演会にて発表

** 阿南工業高等専門学校

*** 日産自動車株式会社
により解いて得られる数值解である。

本研究では, Almen-Laszlo の式と Wempner の式に よる数値結果の精度を, 差分法 ${ }^{3}$ による結果と比較する ことにより，検討する。特にわが国では Almen-Laszlo の式が設計に多く用いられているが，この式の精度が 本研究によって明らかになる。また本研究では実験も 行ったので，その結果についても報告する。

\section{Almen-Laszlo の解, Wempner の解, 及び差分解(本解)の概要}

図 1 に血ばねの形状と，それを規定する寸法の記号 (Di，Do，H，h）を示す。この皿ば初が，上下両縁に接 触した 2 枚の剛体平板によって圧縮されるものとする. なお接触面では，摩擦作用はないものとする。

(1) Almen-Laszlo ${ }^{1)}$ 解

この解は現在わが国で広く用いられており, JISに採 用されているものである。これはエネルギ法による近 似解であり，次の三つの近似仮定のもとに導かれてい る。 
(i) IIIIばねの各微小部分 (殼要素)の回転が，比較的 小さい.

(ii) 変形中も円錐形が保持される.

(iii) 子午線方向のひずみの影響を無視する. ここで, 次の二つの無次元パラメータを定義する.

$$
\begin{aligned}
& \alpha_{\mathrm{o}}=\mathrm{D}_{\mathrm{i}} / \mathrm{D}_{\mathrm{o}} \\
& \mathrm{p}=\mathrm{P} / \mathrm{ED}_{\mathrm{o}} \mathrm{h}
\end{aligned}
$$

ただし P は圧縮荷重であり，Eは縦弾性係数である。 また，皿ばねのたわみ量，すなわち上縁と下縁の近寄 り量を $\delta$ とする。このとき次式が成立する。

$$
\mathrm{p}=\frac{4 \mathrm{C} \delta}{\left(1-\Gamma^{2}\right) \mathrm{D}_{0}{ }^{3}}\left\{(\mathrm{H}-\delta)\left(\mathrm{H}-\frac{\delta}{2}\right)+\mathrm{h}^{2}\right\}
$$

ここに

$$
\mathrm{C}=\left(\frac{1+\alpha_{0}}{1-\alpha_{0}}+\frac{2}{\ln \alpha_{0}}\right) \pi\left(\frac{1}{1-\alpha_{0}}\right)^{2}
$$

なお「はポアソン比である。式(2)が，皿ばねの荷重一 たわみ関係を求めるための, Almen-Laszlo の式である.

(2) Wempner ${ }^{2)}$ 解

この解もエネルギ法による近似解であるが，上述の Almen-Laszlo の解における仮定(iii)を外して子午線方向 のひずみの影響を考慮している点で，上述の解と異な っている.

初期円錐角を $\phi$ として, 次の無次元パラメータを定 義する。

$$
\gamma=2 \mathrm{~h} \cos \phi / \mathrm{D}_{\mathrm{o}}
$$

このとき次式が成立する.

$$
\mathrm{p}=\mathrm{M} \frac{\delta}{\mathrm{D}_{\mathrm{o}}{ }^{3}}(\mathrm{H}-\delta)\left(\mathrm{H}-\frac{\delta}{2}\right)+\mathrm{N} \frac{\delta}{\mathrm{D}_{\mathrm{o}}}
$$

ここに

$$
\begin{aligned}
& \mathrm{M}=\frac{1-\Gamma^{2}}{2\left(1-\alpha_{\mathrm{o}}{ }^{4}\right)}\left\{\frac{\alpha_{0}\left(\ln \alpha_{0}\right)^{2}}{\alpha_{0}{ }^{2}-1}+\frac{1-\alpha_{0}{ }^{2}}{4}\right\} \\
& \mathrm{N}=-\frac{\gamma^{2}}{12} \frac{\ln \alpha_{0}}{\left(1-\alpha_{0}\right)^{2}}
\end{aligned}
$$

式が(5)が Wempner の式である.

(3) 差分解 $(\text { 本解 })^{3)}$

皿ばねは, その形状から見て, せっ頭円錐款 (Truncated conical shell)であるといえるが，これは軸対称殼 の一つの例である。殼厚一定の弾性の軸対称殼が軸対 称荷重を受けて変形する場合の, 荷重, 変形及び応力 の間の関係を求める問題に関しては, 現在では電子計 算機を用い, 有限要素法, 差分法, あるいは数值積分 法等の数值解法によって, 数值的に精度の高い解を得 ることができる.筆者の一人 ${ }^{31} は$ 他の共同研究者ととも に, 殸の変形量が殼厚に比べて小さくない場合の, い わゆる大たわみ問題 (すなわち幾何学的非線形問題)を 差分法によって解く方法について研究したが, ここで はその解法を用いる.

差分法は, 微分方程式の数值解法の一つとして, 古 くより用いられてきたものである。いま簡単な例とし
て, 独立変数を $\mathrm{x}$, 従属変数を $\mathrm{y}$ とする 2 階線形常微 分方程式を考える。与えられた $\mathrm{x}$ の有限領域 $\left(\mathrm{x}_{0}, \mathrm{x}_{\mathrm{N}}\right)$ を等間隔 $\Delta \mathrm{x}$ にて $\mathrm{N}$ 分割して, 分割点の $\mathrm{x}$ 座標を $\mathrm{x}_{\mathrm{i}}(\mathrm{i}=$ 1 （N-1)) とし, $\mathrm{x}_{\mathrm{i}}(\mathrm{i}=0$ ～N $)$ の各点に対する $\mathrm{y}$ を $\mathrm{y}_{\mathrm{i}}$ とする.そして, 中間差分点 $\mathrm{x}_{\mathrm{i}}(\mathrm{i}=1 \sim(\mathrm{N}-1))$ に対し て, 中間差分近似式

$$
\left.\begin{array}{l}
{\left[\frac{d y}{d x}\right]_{i}=\frac{y_{i+1}-y_{i-1}}{2(\Delta x)}} \\
{\left[\frac{d^{2} y}{d x^{2}}\right]_{i}=\frac{y_{i+1}-2 y_{i}+y_{i-1}}{(\Delta x)^{2}}}
\end{array}\right\}
$$

を用いて，与えられた微分方程式より $\mathrm{y}_{\mathrm{i}}(\mathrm{i}=0$ ～N ) に関 する 1 次方程式を $\mathrm{N}-1$ 個作る. 一方, 両端 $\mathrm{x}_{0}, \mathrm{x}_{\mathrm{N}}$ に 対する境界条件に対して, 必要あれば前進差分近似式

$$
\left[\frac{\mathrm{dy}}{\mathrm{dx}}\right]_{0}=\frac{-3 \mathrm{y}_{0}+4 \mathrm{y}_{1}-\mathrm{y}_{2}}{2(\Delta \mathrm{x})}
$$

または後進差分近似式

$$
\left[\frac{\mathrm{dy}}{\mathrm{dx}}\right]_{\mathrm{N}}=\frac{3 \mathrm{y}_{\mathrm{N}}-4 \mathrm{y}_{\mathrm{N}-1}+\mathrm{y}_{\mathrm{N}-2}}{2(\Delta \mathrm{x})}
$$

を用いて，二つの 1 次方程式を得る。以上において得 られた計 $\mathrm{N}+1$ 個の 1 次方程式を連立方程式として, Gauss の消去法等を用いて電子計算機により解き， $y_{i}$ $(\mathrm{i}=0 \sim \mathrm{N})$ を求める.これが線形常微分方程式の差分法 による解法の概要である。

IIIIばねの問題の支配微分方程式は, 独立変数が款厚 中央面上の子午線に沿う長さの座標であり, 従属変数 は，子午線上の任意点における二つの変位成分と一つ の曲げモーメントの計 3 個の, 連立 2 階常微分方程式 として表わされる。ただし，本問題は非線形問題であ るから, 上記の三つの量の増分量を徒属変数とし, 皿 ばねのたわみ量を少しずつ增加させていき, その各段 階ごとに前述の常微分方程式の解法を何度も繰返し, 解が数值的に収束したことを確かめてから次の増分段 階に移る，という面倒な手続きを採らなければならな い.

\section{3. 計算例と実験例}

図 2 図 9 において，8個の試験片を用いて得られ た荷重一たわみ線困の実験結果と, それに対して前章 で述べた三つの解法により得られた理論結果とを比較 して示す。実験に用いた試験片の寸法は，表 1 に示す とおりである。

これらの各場合において，三つの理論解の間には相 当の差が認められる。また Almen-Laszlo の解よりも, Wempnerの解の方が差分解に近い. 実験值は負荷の場 合と除荷の場合とで異なるが，この差異は，孟ばねの 両縁と負荷体の平面との間に生じる摩擦によるもので ある。その他の諸原因による実験誤差も実験值に含ま れていることを考慮して図 2 図 9を通観すると, 実 験結果にもつとも近い理論解は差分解であるといえよ j。 


\begin{tabular}{|r|c|c|c|c|c|}
\hline \multicolumn{5}{|c|}{ 試験片の寸法 } & $(\mathrm{mm})$ \\
\hline 四 & Do & Di & $H$ & $\mathrm{~h}$ & $\mathrm{R}$ \\
\hline 2 & 265.0 & 130.5 & 6.0 & 2.7 & 0.5 \\
\hline 3 & 225.5 & 112.0 & 6.5 & 3.0 & 0.6 \\
\hline 4 & 265.0 & 130.5 & 6.0 & 4.0 & 0.8 \\
\hline 5 & 160.0 & 82.0 & 4.5 & 3.0 & 0.6 \\
\hline 6 & 265.0 & 130.5 & 6.0 & 5.0 & 1.0 \\
\hline 7 & 225.0 & 112.0 & 6.0 & 5.0 & 1.0 \\
\hline 8 & 225.0 & 112.0 & 5.0 & 8.0 & 1.6 \\
\hline 9 & 160.0 & 82.0 & 5.0 & 6.0 & 1.2 \\
\hline
\end{tabular}

差分解には，数值解としての計算誤差が含まれる。 すなわち，典ばねの子午線上で差分分割をするときの 分割数 $\mathrm{N}$, 両縁の相対変位を少しずつ増加させてい く各段階での, 繰返し計算に打ける解の収束状態の二 つが, 計算誤差の主因と考えられる。筆者らは，Nに ついては種々の值を与えて計算をし，また繰返し計算 における解の収束状況を調べながらその繰返し数を定 めることによって, 本論文中で線図で示した差分計算 の結果は, 四上ではほとんど変らないことを確かめて いる。すなわち本解法により求められた荷重一たわみ 線図は，ほぼ正確であるとしてよい，と考える。
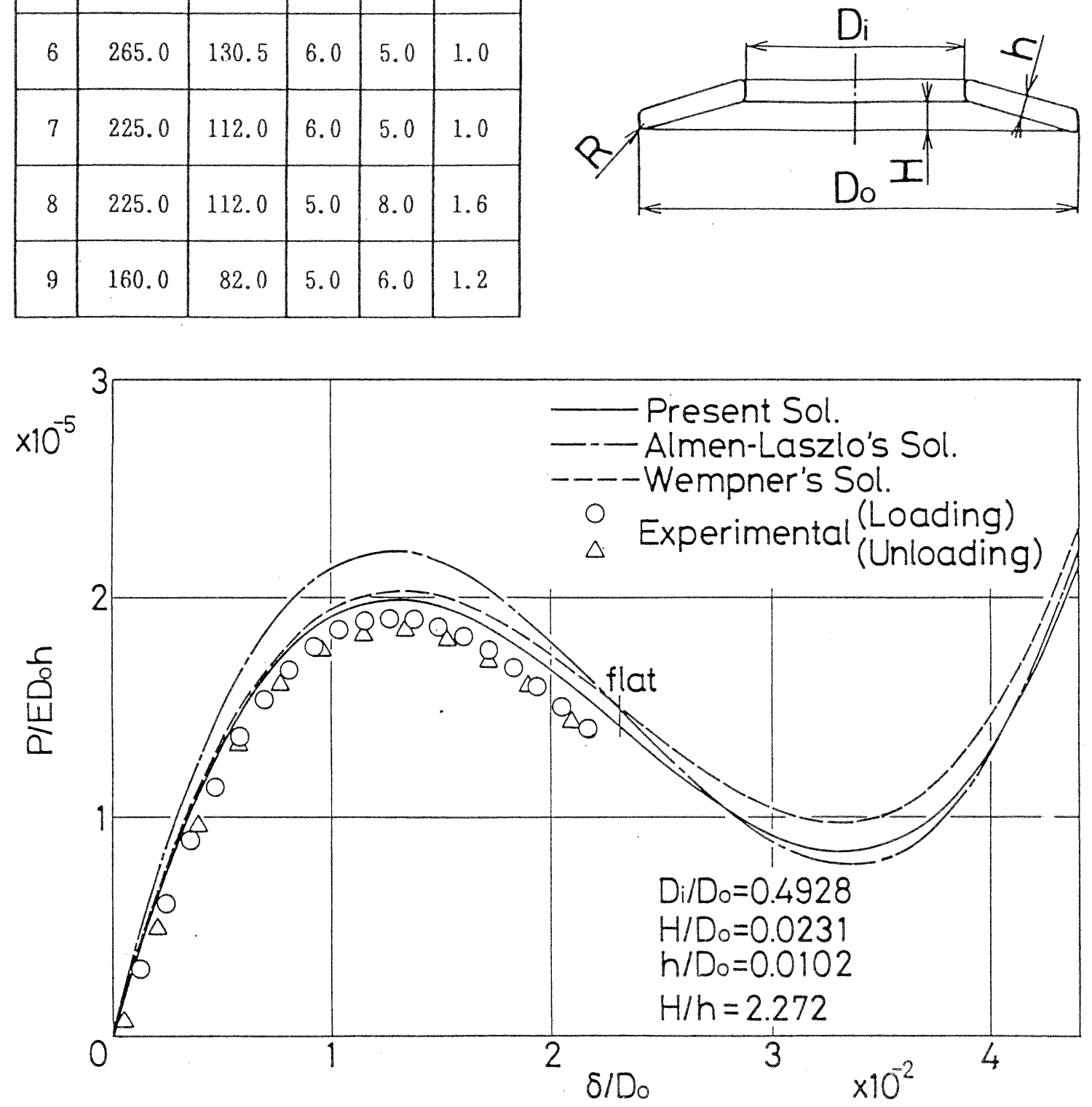

図 1。且ばねの形状 


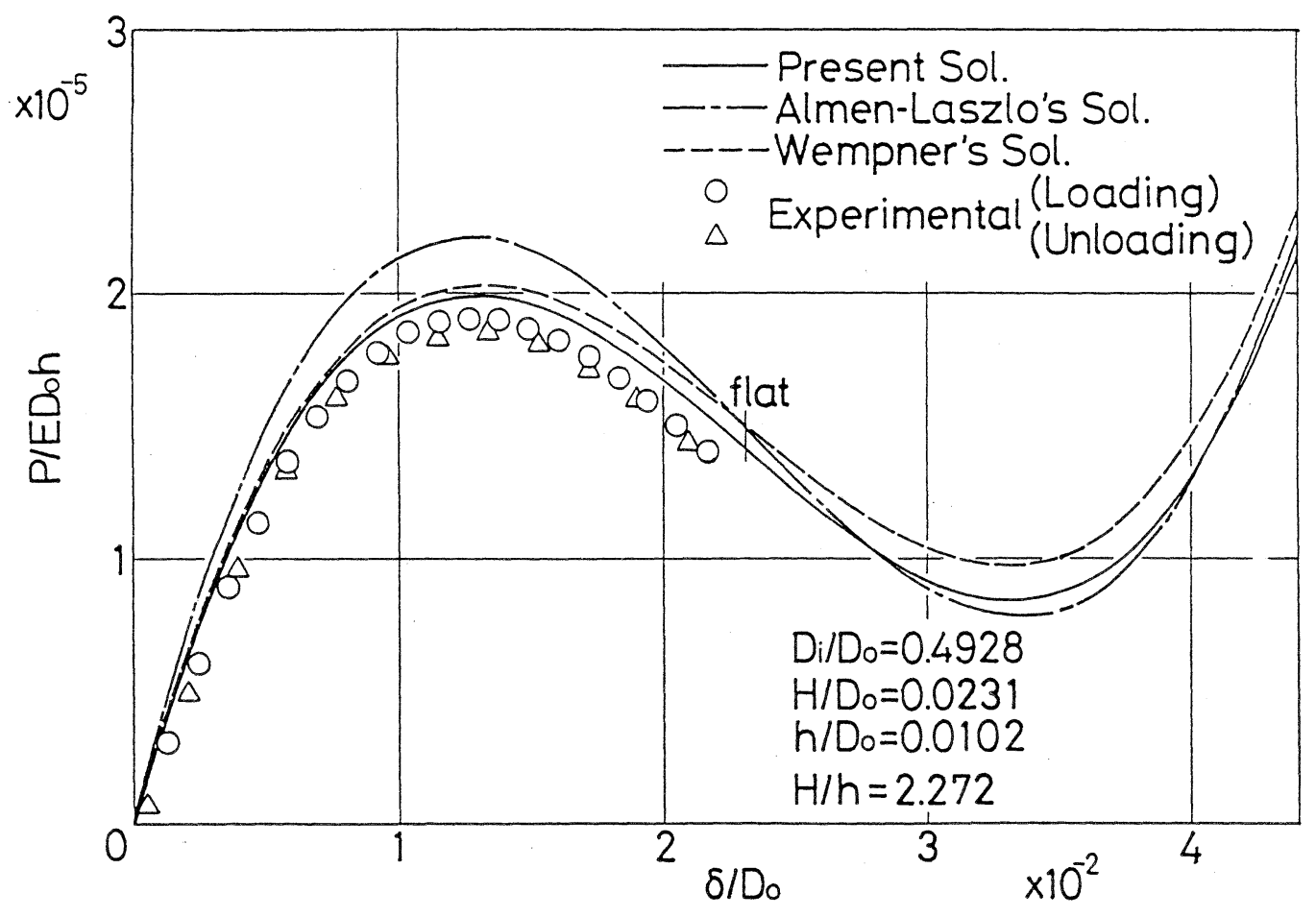

図 2。荷重一たわみ線図（理論解と実験值）(1)

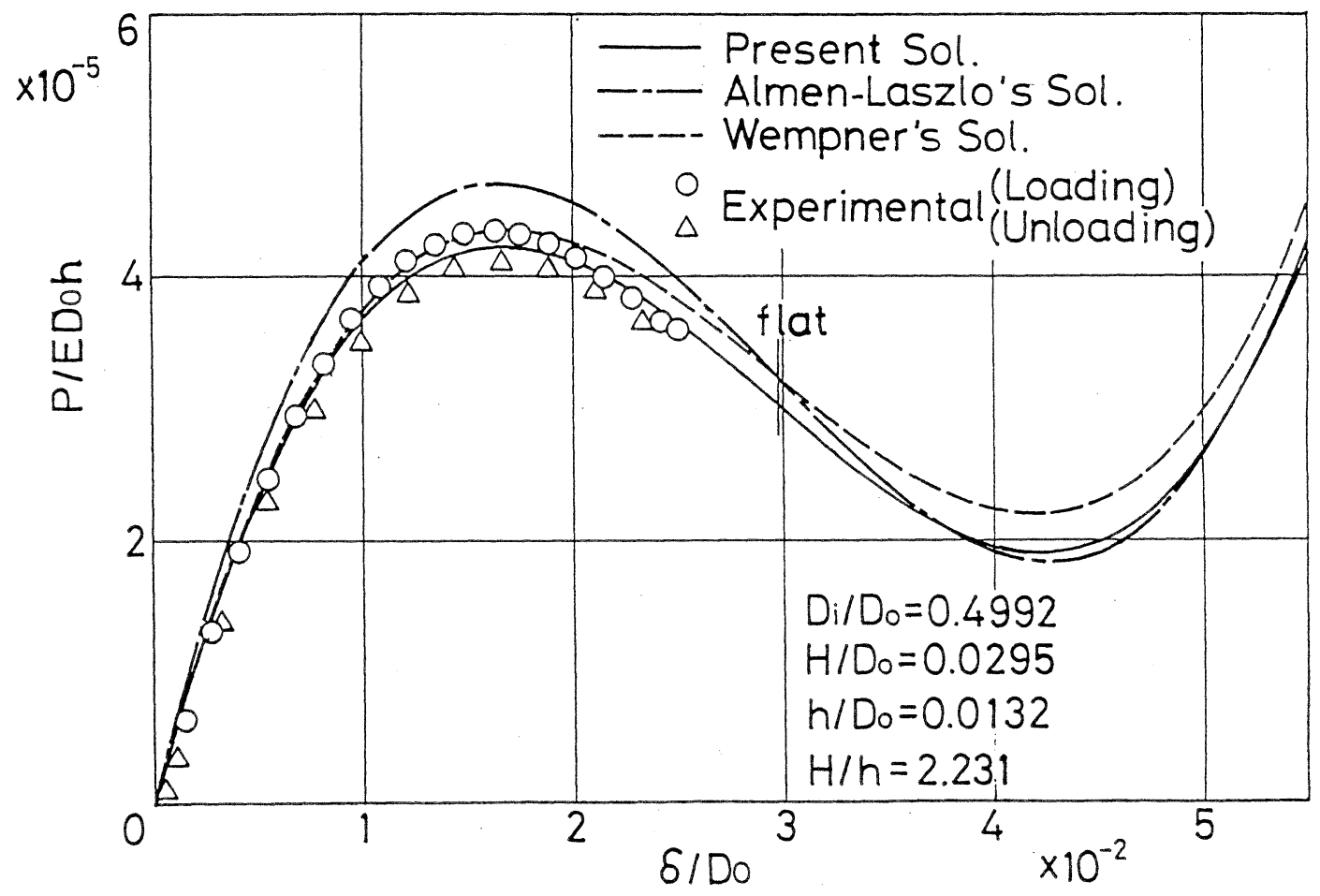

図 3 。荷重一たわみ線図（理論解と実験值）(2) 


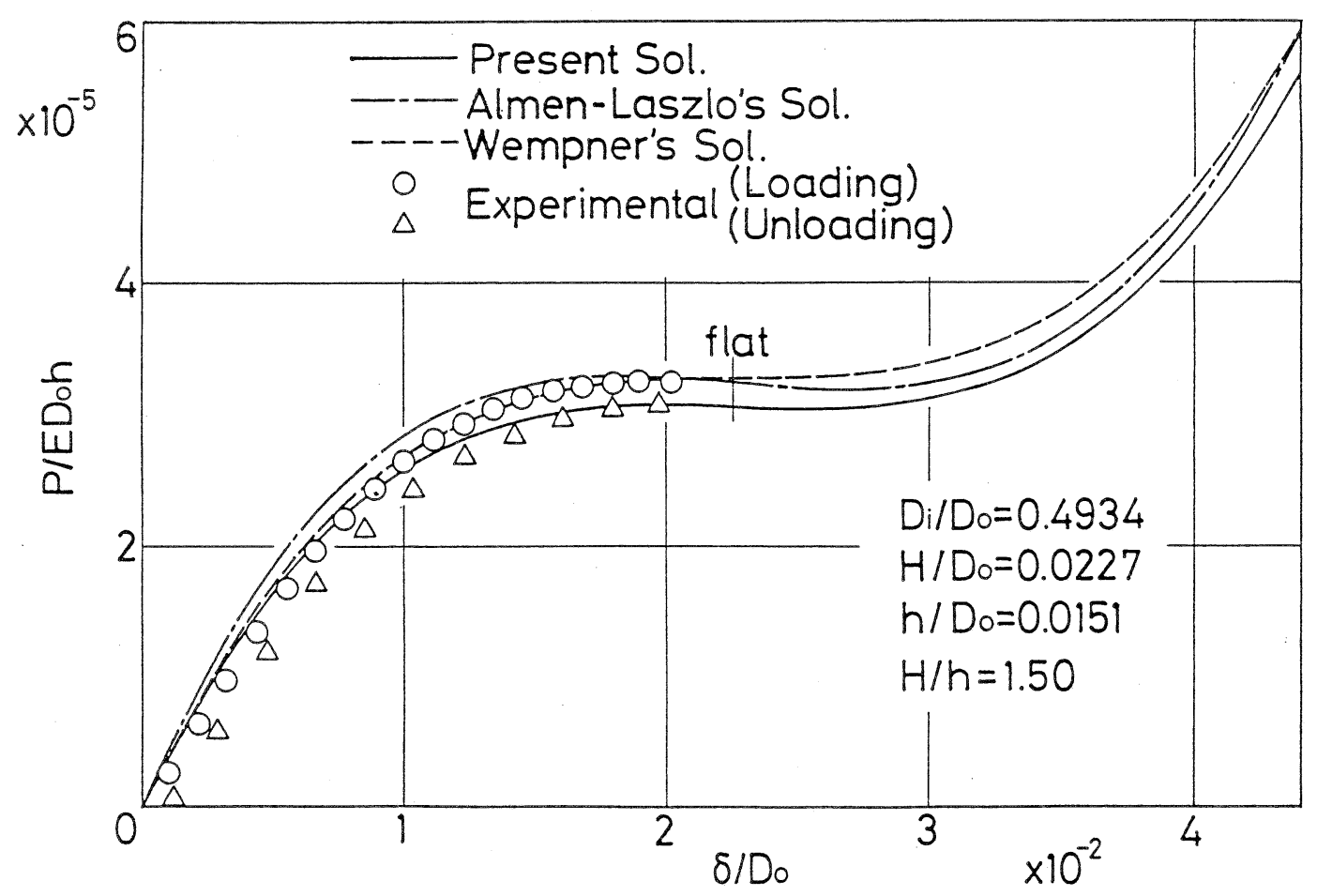

図 4.荷重一たわみ線困（理論解と実験値）(3)

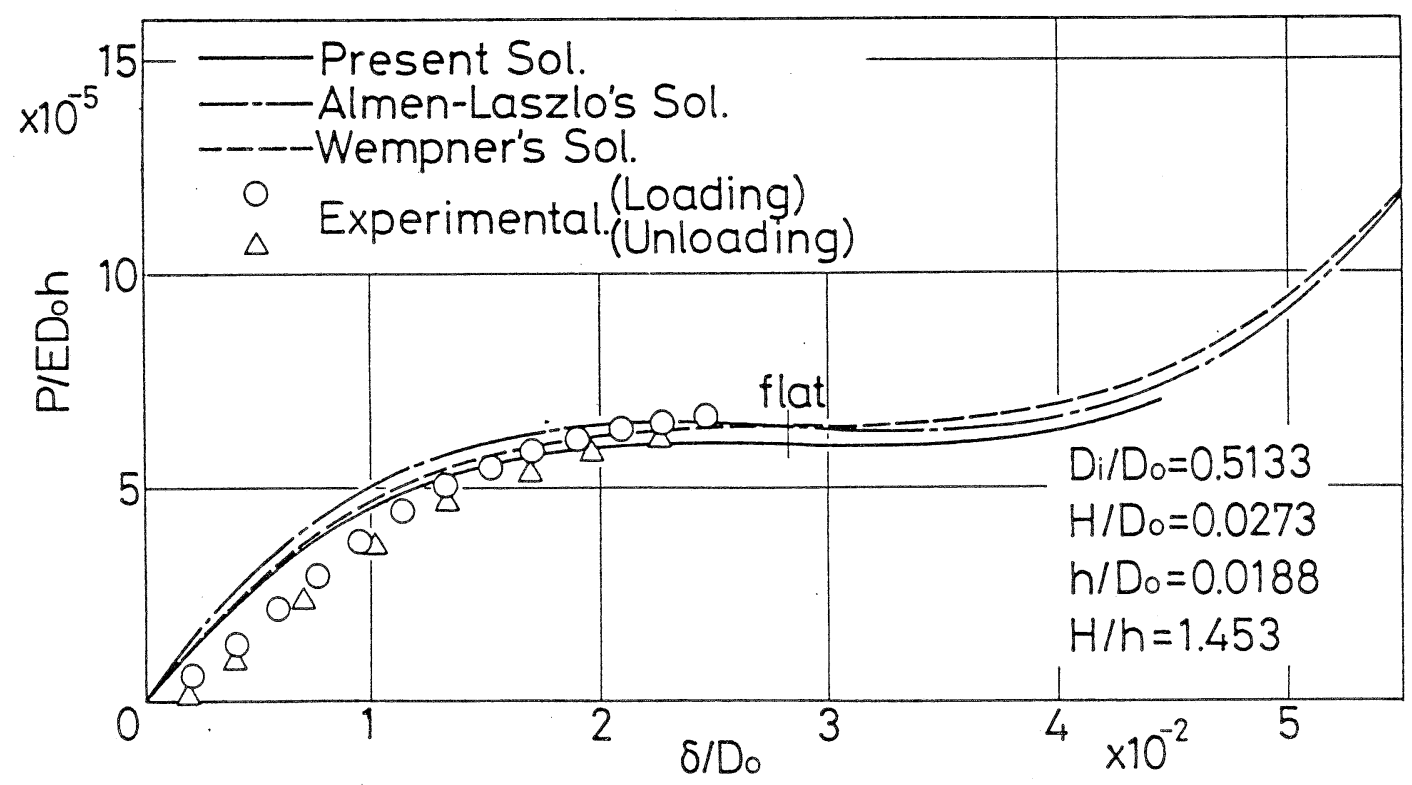

図 5。荷重一たわみ線困（理論解と実験値）(4) 


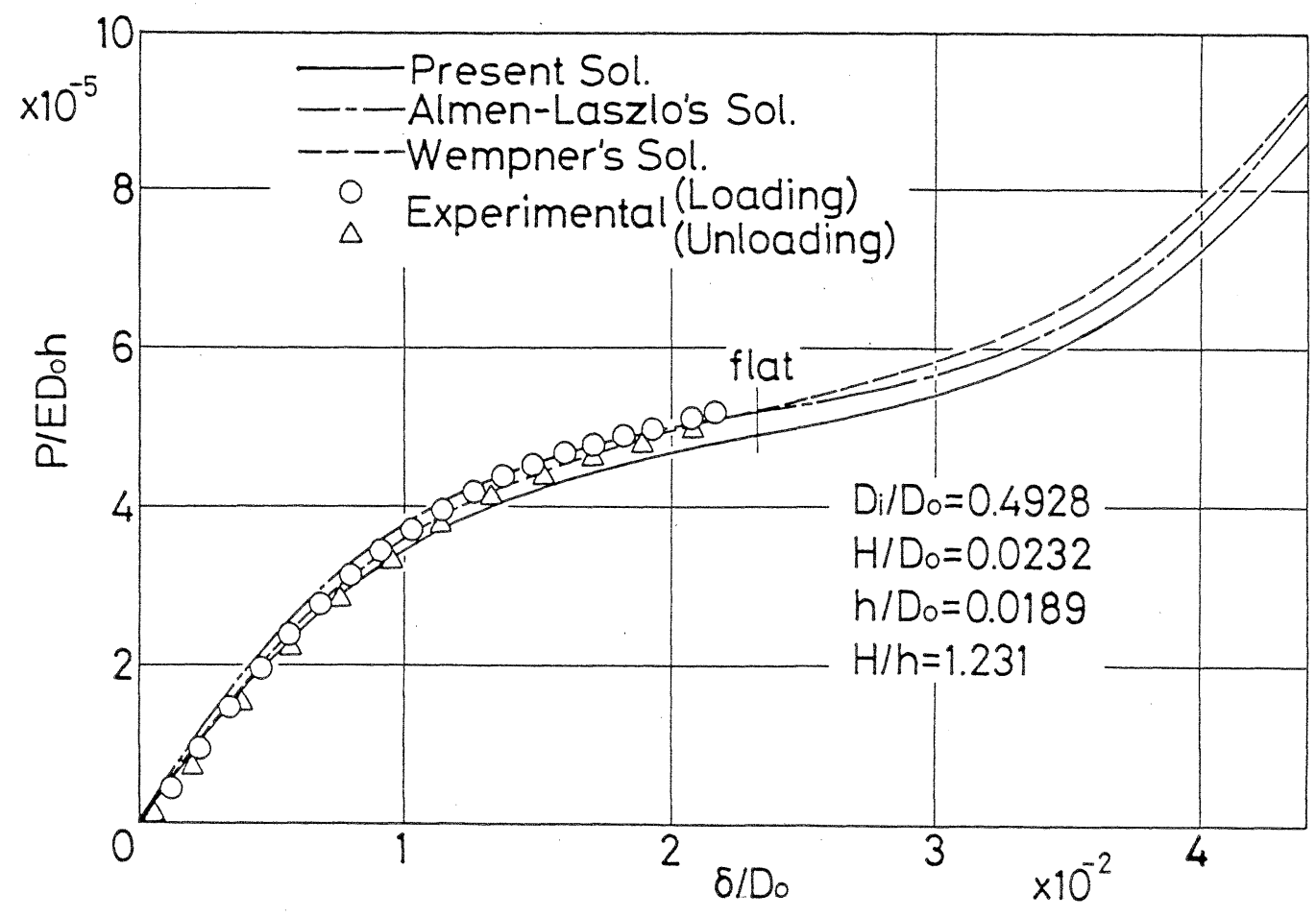

図 6. 荷重一たわみ線図（理論解と実験值）(5)

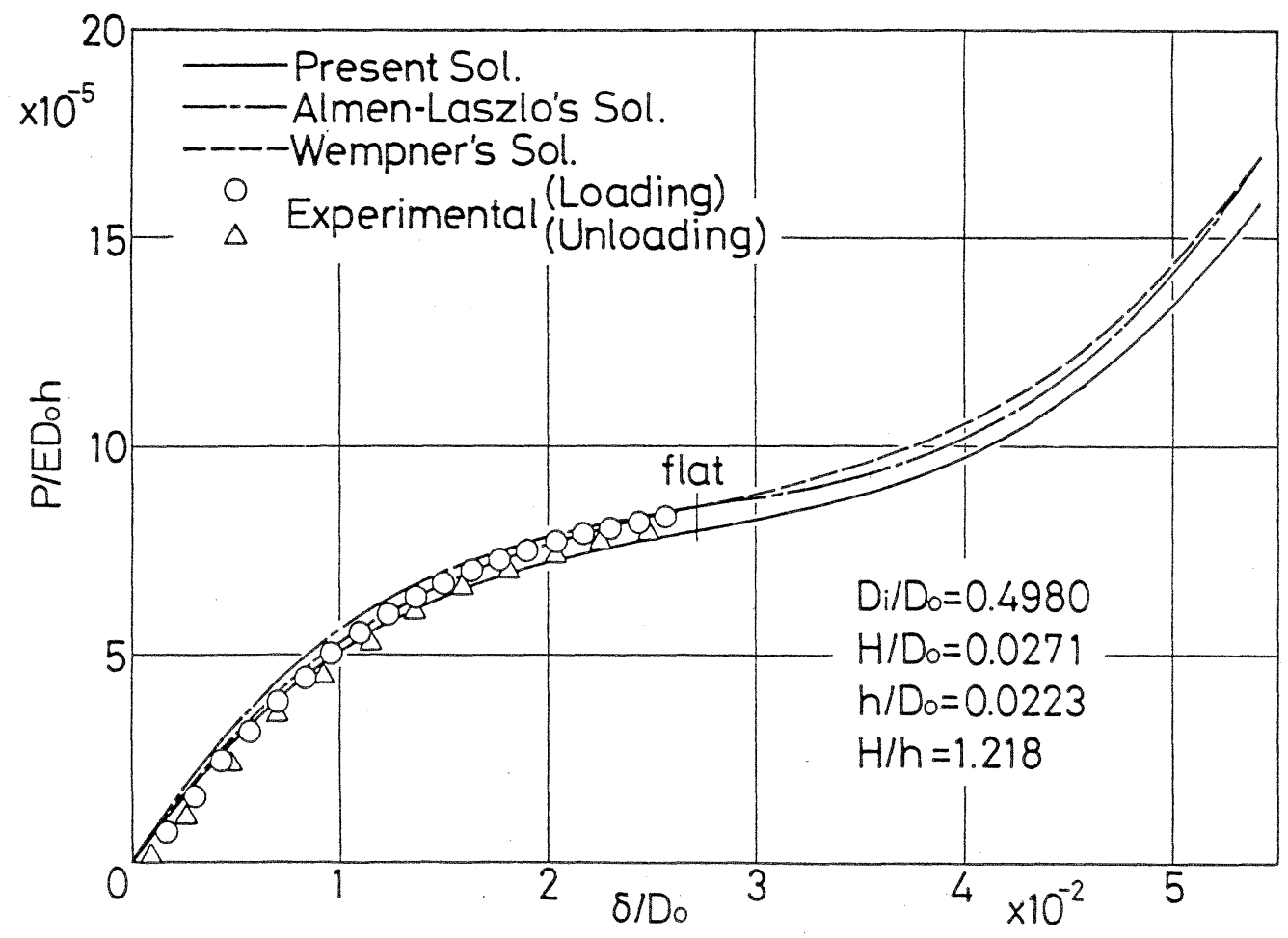

図 7。荷重一たわみ線図（理論解と実験値）(6) 


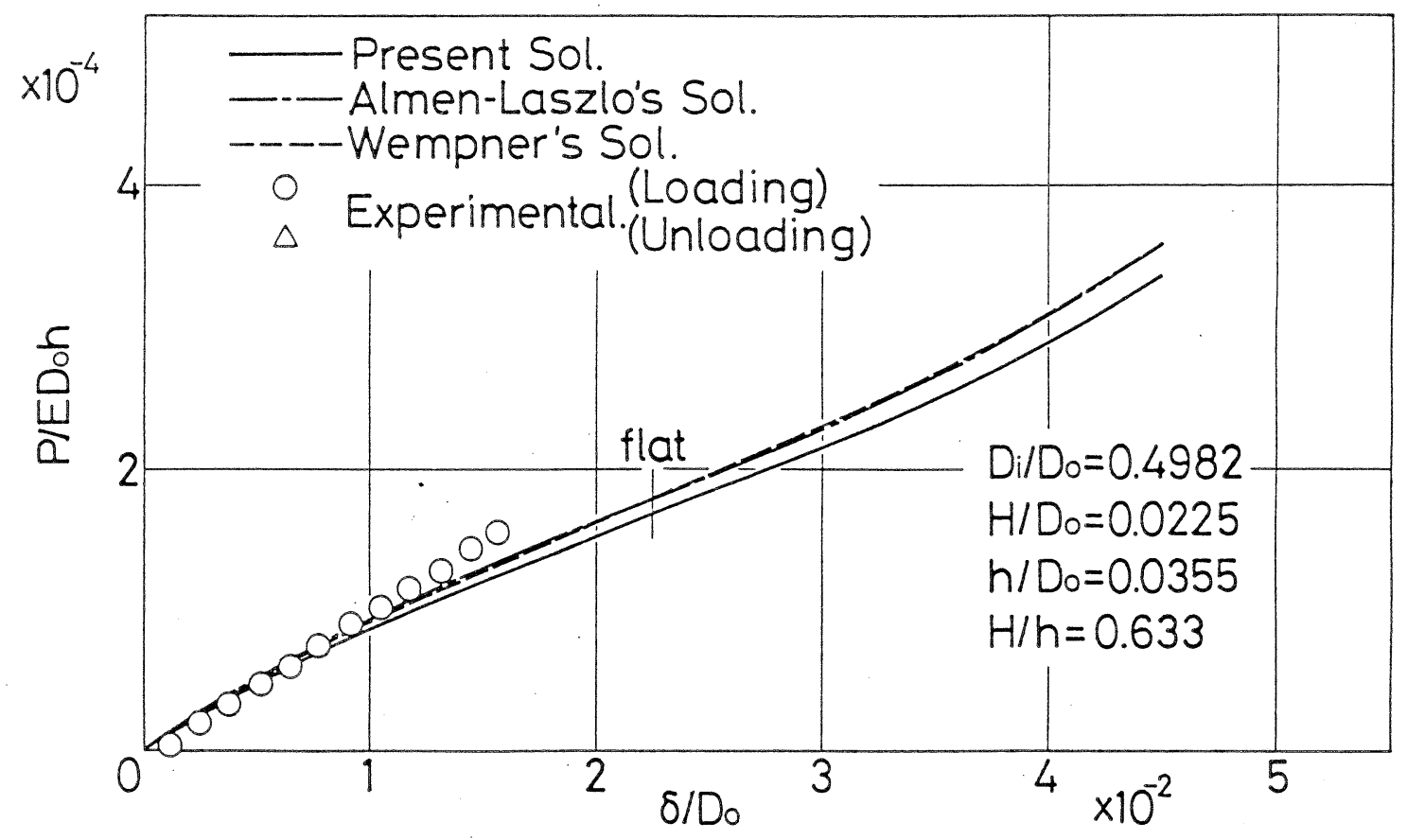

図 8、荷重一たわみ線図（理論解と実験值）（7）

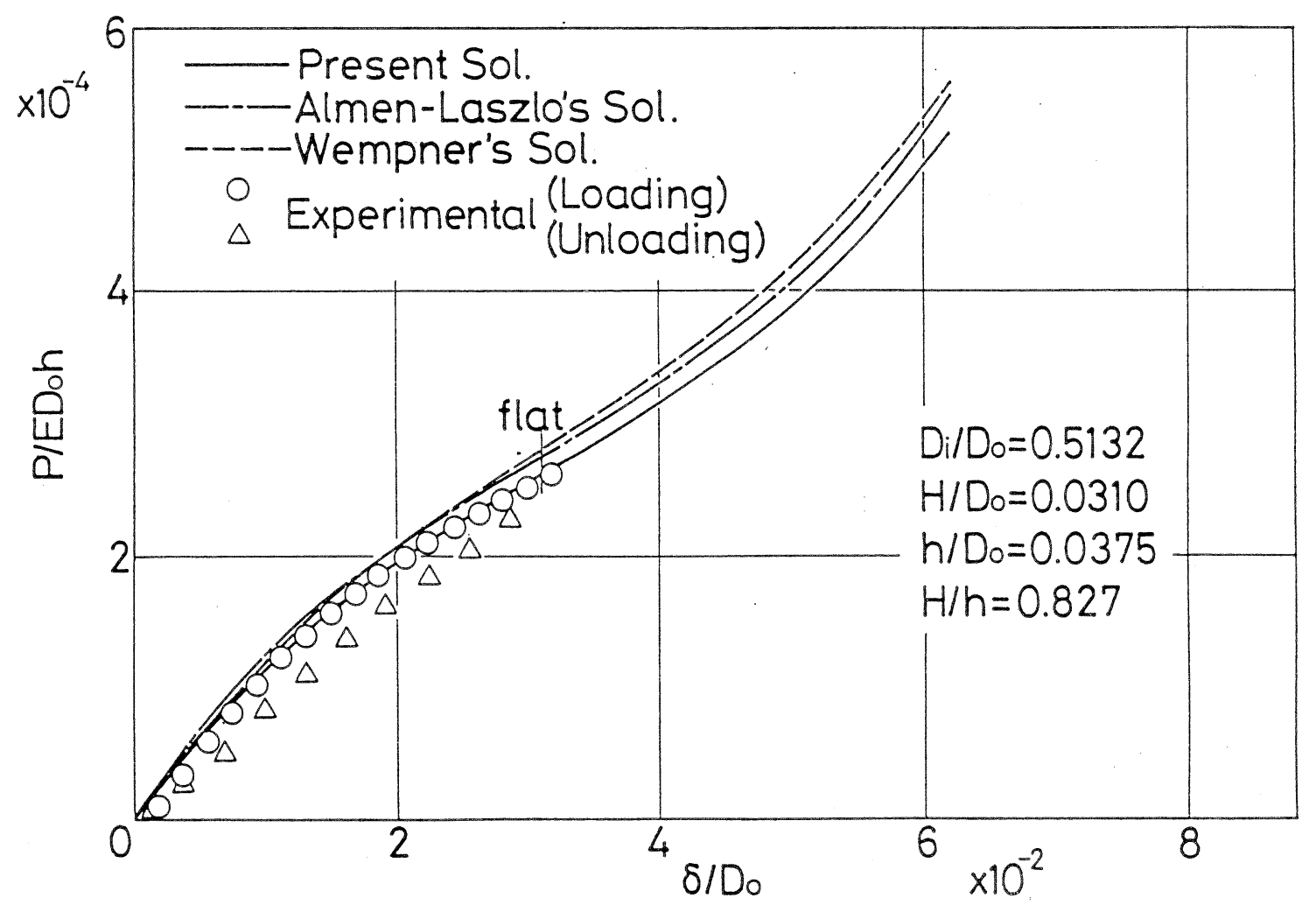

図 9。荷重一たわみ線図（理論解と実験値）(8) 


\section{4. 三つの解法による荷重一たわみ線図の比較}

図 1 に示すように, 皿ばねの形状を規定する寸法は, $\mathrm{D}_{\mathrm{o}}, \mathrm{D}_{\mathrm{i}}, \mathrm{H}, \mathrm{h}$ の 4 個であるから，無次元パラメー夕は 3 個である。これらを $\mathrm{H} / \mathrm{h}, \mathrm{H} / \mathrm{D}_{0}, \mathrm{D}_{\mathrm{i}} / \mathrm{D}_{\mathrm{o}}$ とする.

図 2 〜図9の図中に示すように，実験に用いた8個 の試騟片の無次元パラメー夕は， $\mathrm{D}_{\mathrm{i}} / \mathrm{D}_{0}$ と $\mathrm{H} / \mathrm{h}$ がほと んど同じで, $\mathrm{H} / \mathrm{D}_{0}$ の值のみが異なる二つずつの組合せ， すなわち图 2 と図 3 , 図 4 と図 5, 図 6 と図 7, 図 8
と図 9，の各組合せに分けられる。そして，それらの 組合せの二つの図を比較すると, $\mathrm{H} / \mathrm{D}_{0}$ の値が異っても， 荷重一たわみ線図における三つの理論解の相互間の関 係は，ほとんど同じであることがわかる。そこで $\mathrm{H} / \mathrm{D}$ 。 の影響をより詳細に調べることは今後の問題として, ここでは残る二つのパラメータ $\mathrm{H} / \mathrm{h}$ と $\mathrm{D}_{\mathrm{i}} / \mathrm{D}_{0}$ の影響を 調べることにする。

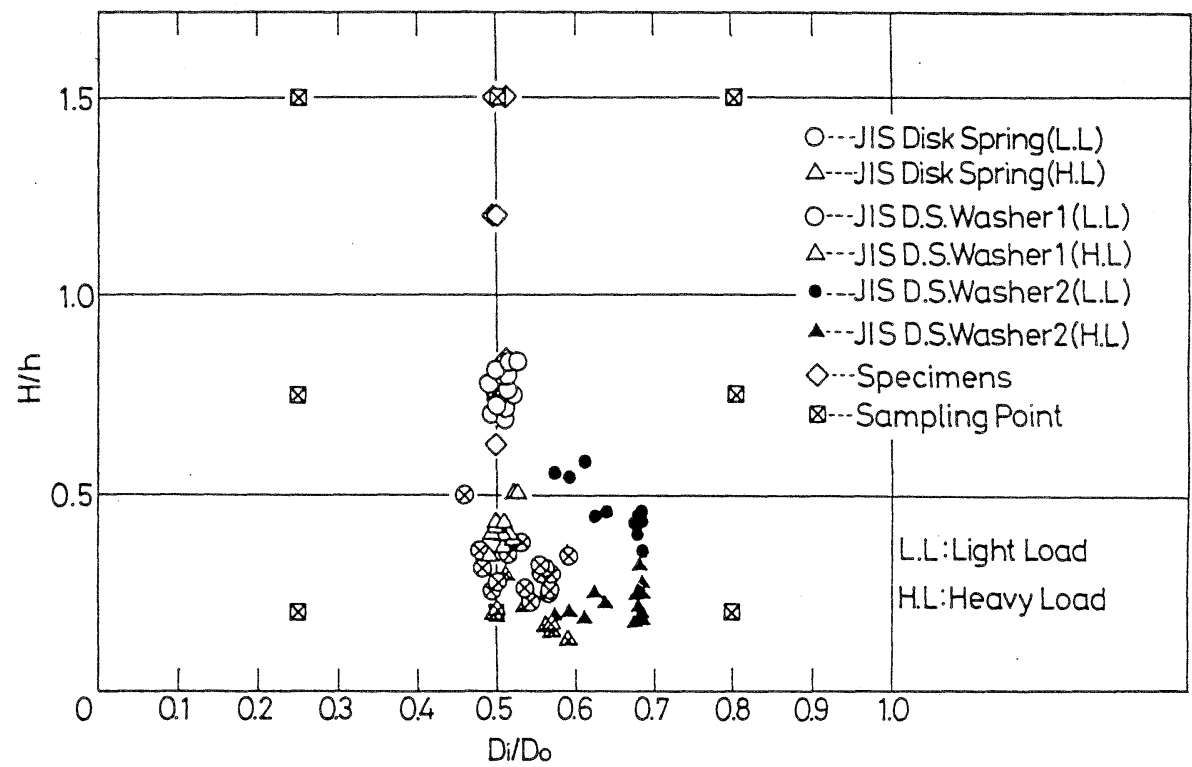

図 10. 形状パラメータ (H/h, Di/Do)

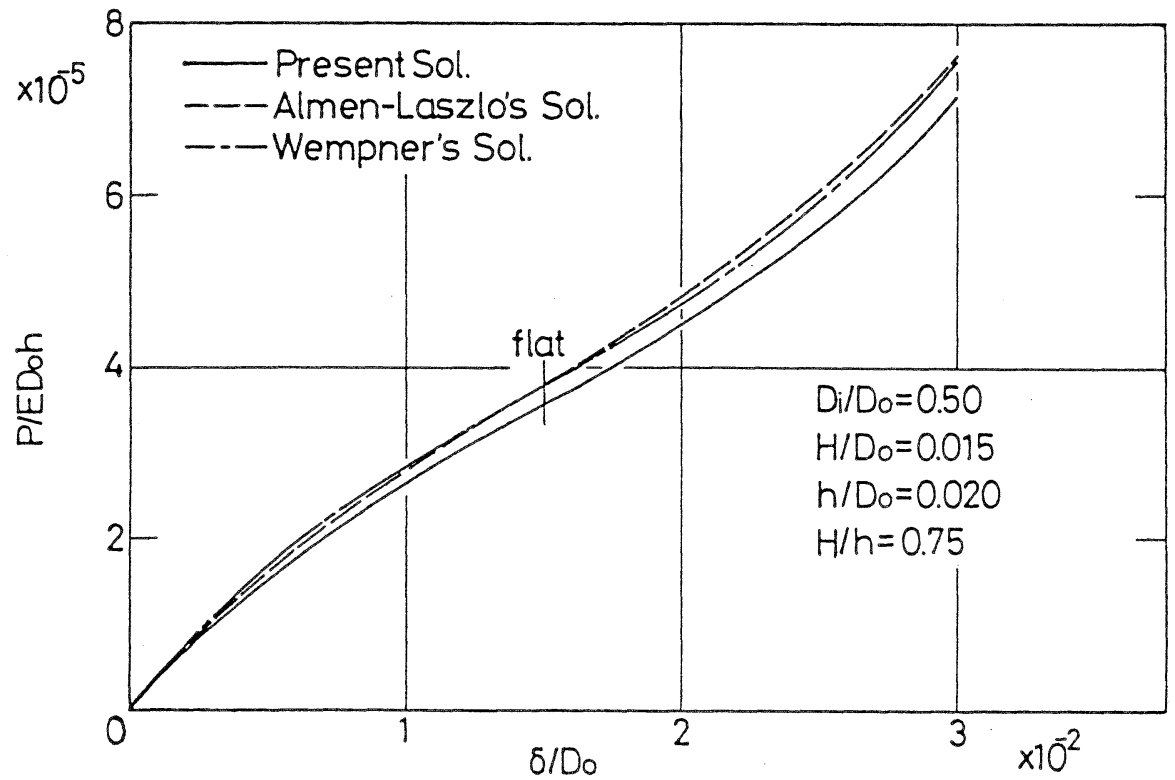

図 11，荷重一たわみ線図（理論解）（1） 


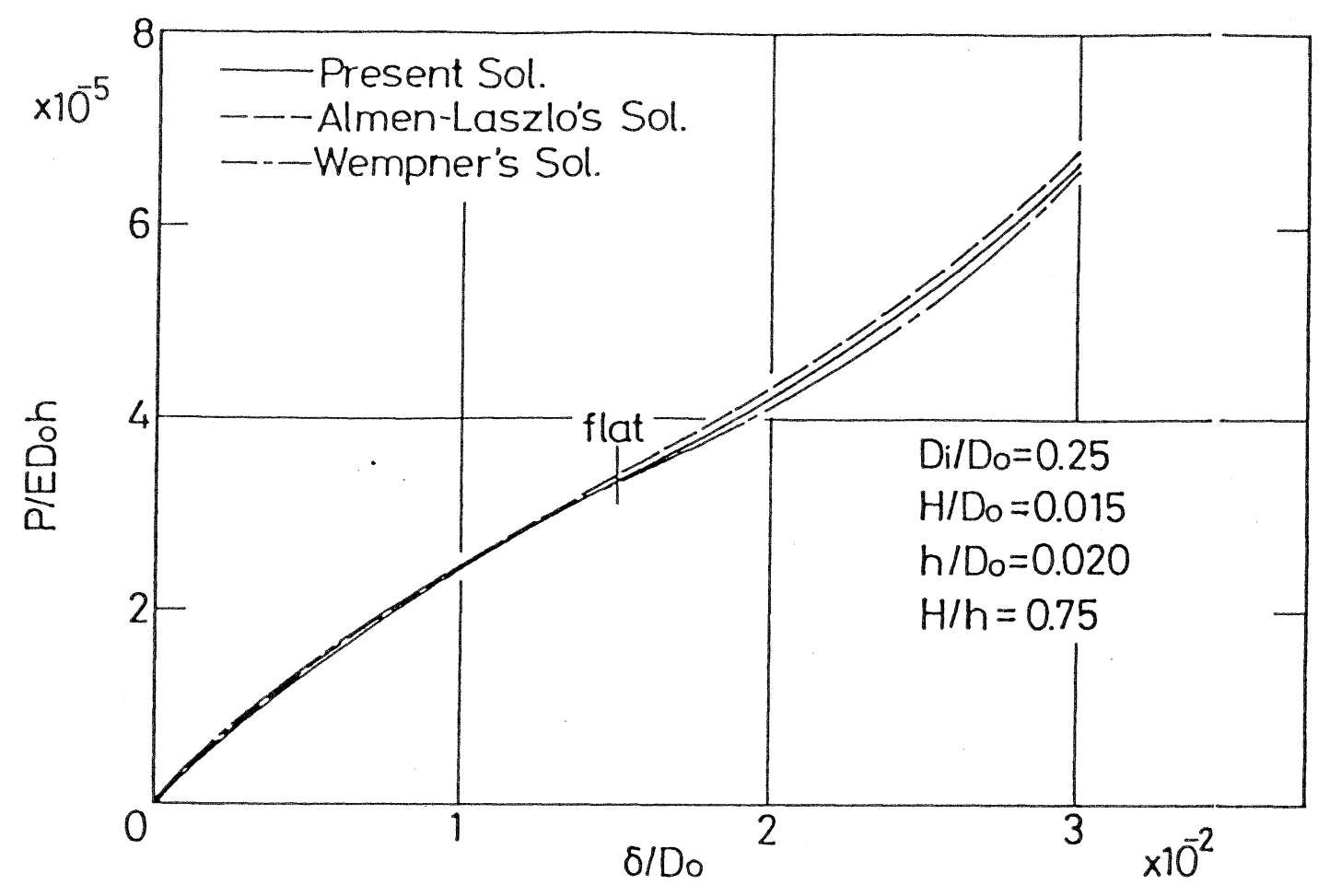

図 12. 荷重一たわみ線図（理論解）(2)

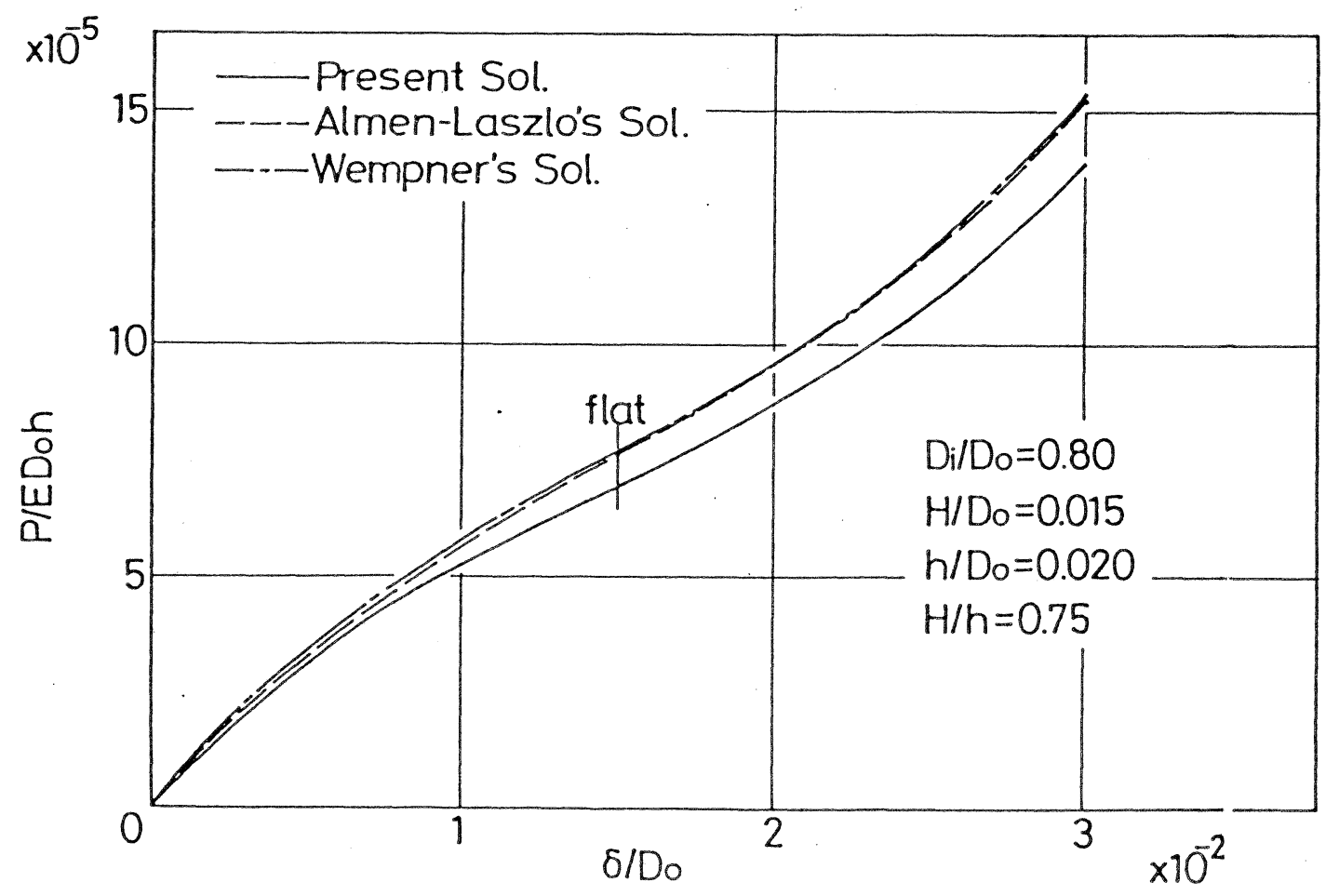

図 13. 荷重一たわみ線困（理論解）(3) 


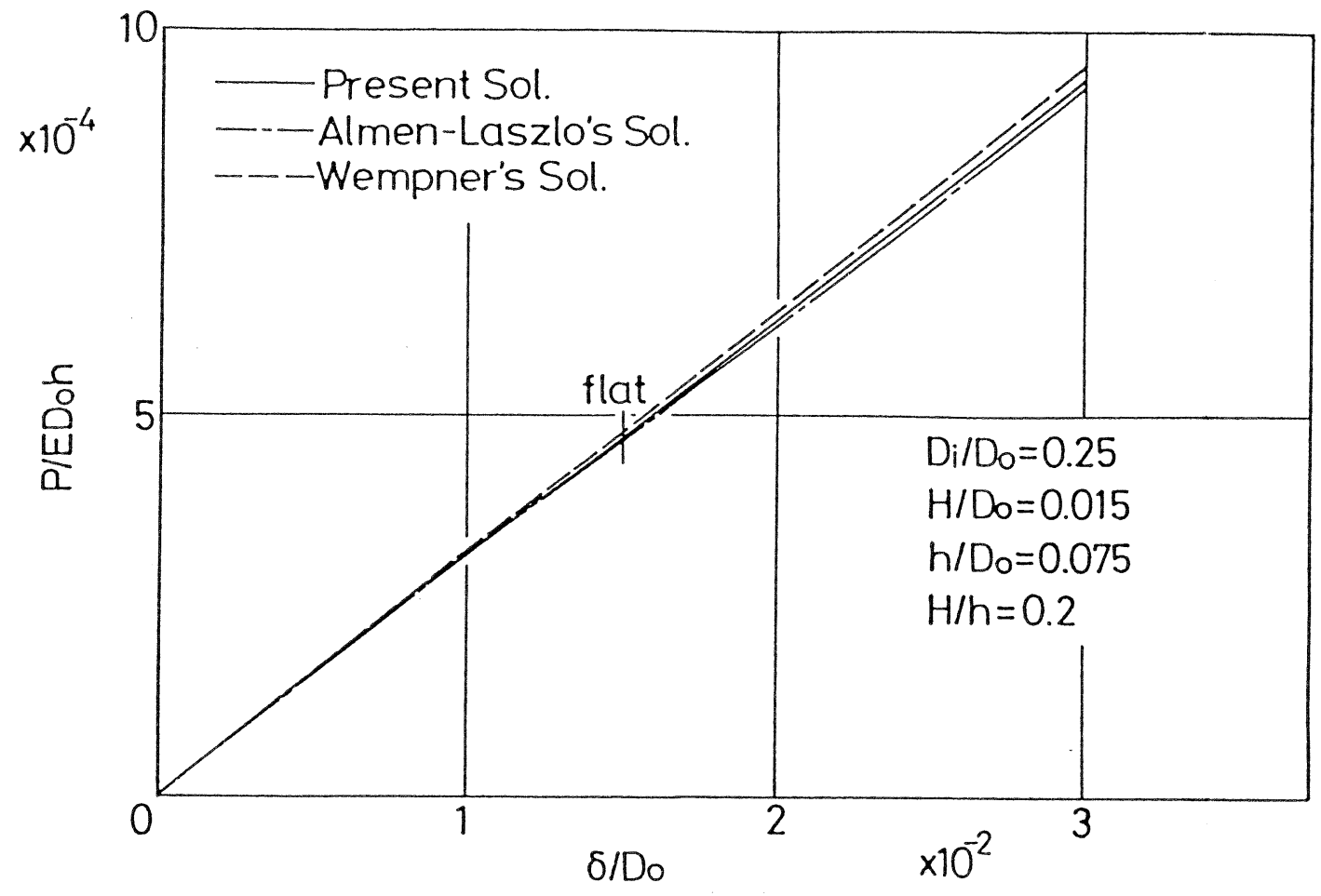

図 14. 荷重一たわみ線図（理論解）(4)

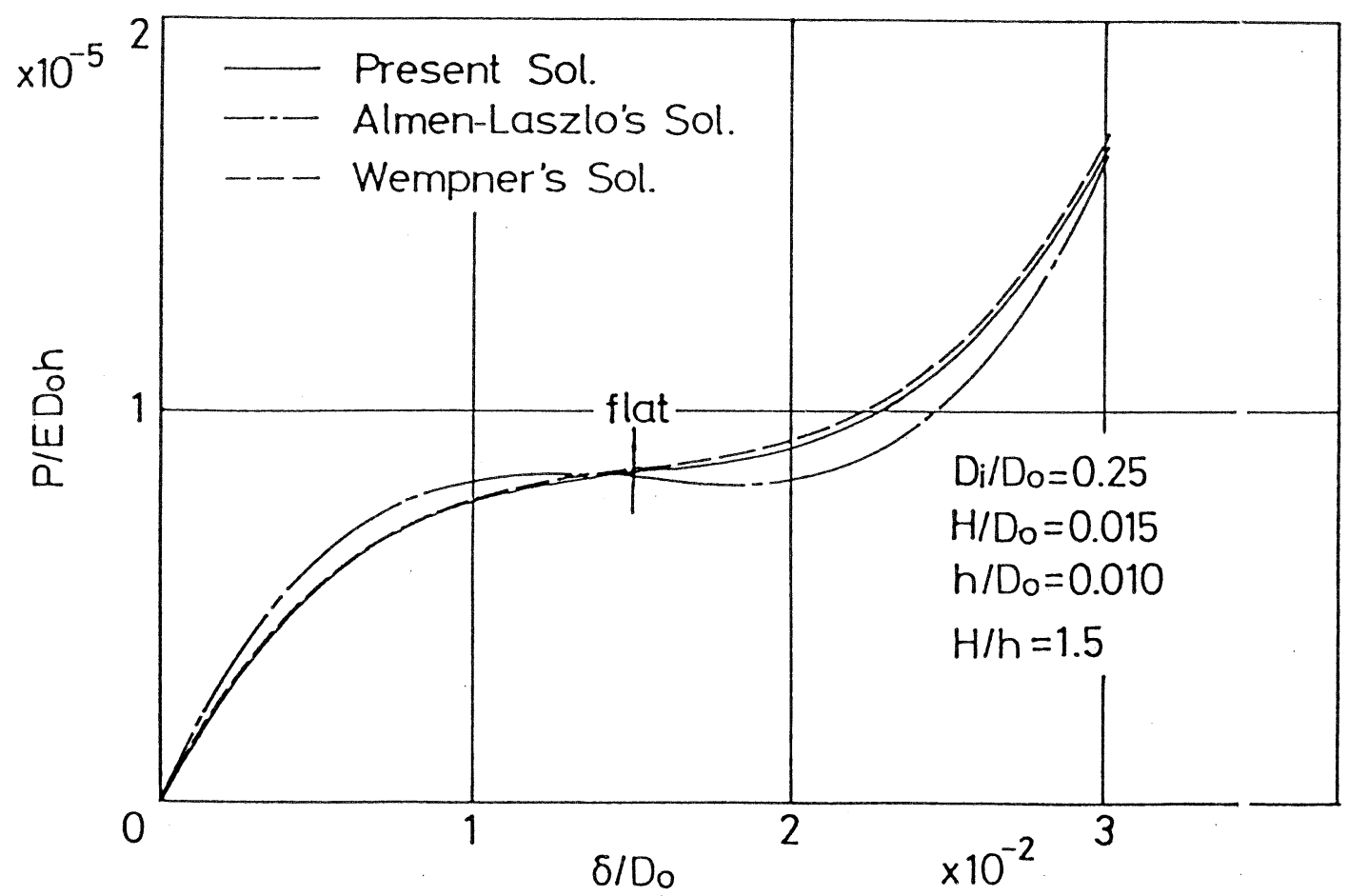

図 15. 荷重一たわみ線図 (理論解) (5) 


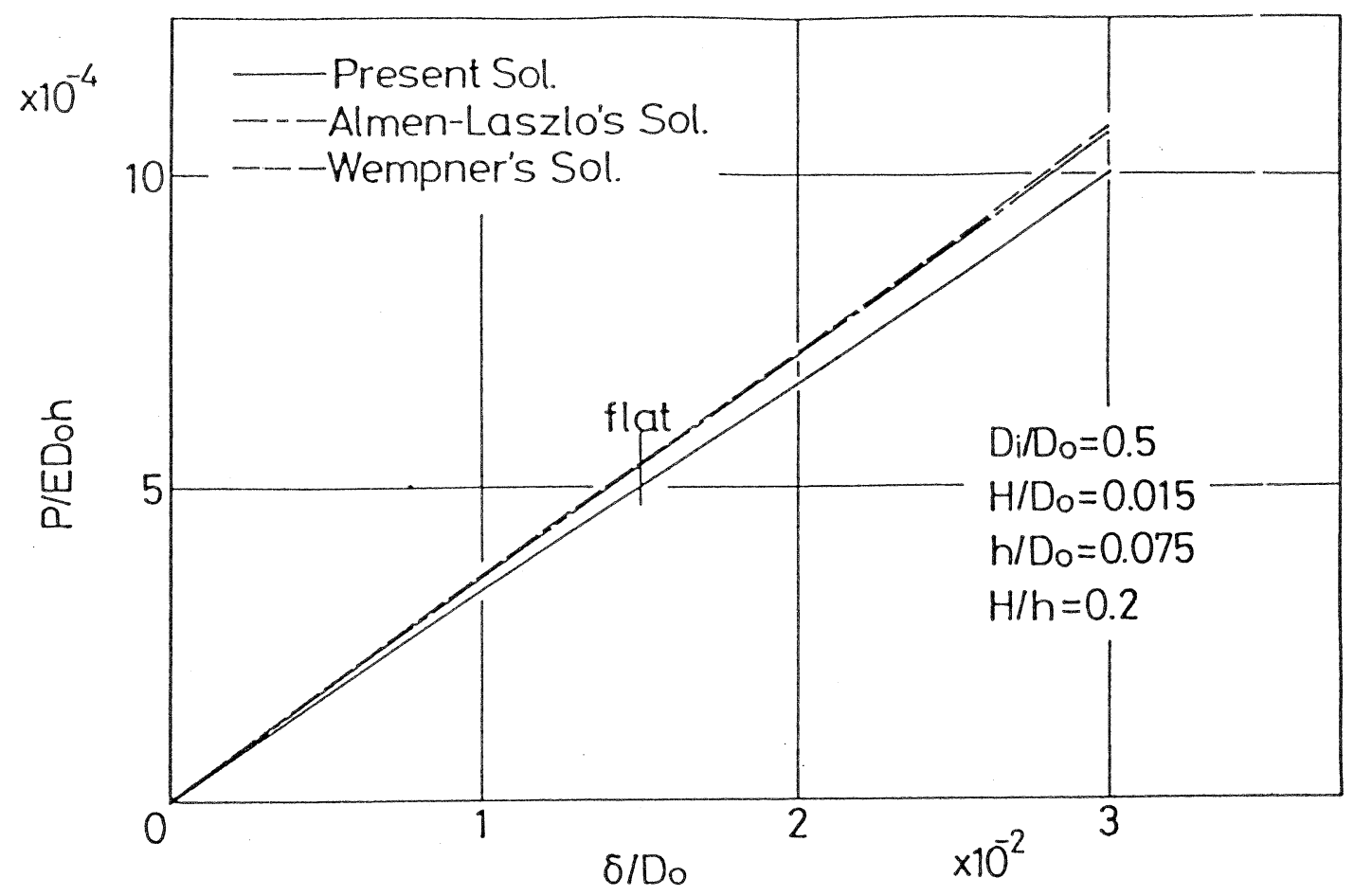

図 16. 荷重一たわみ線闵（理論解）(6)

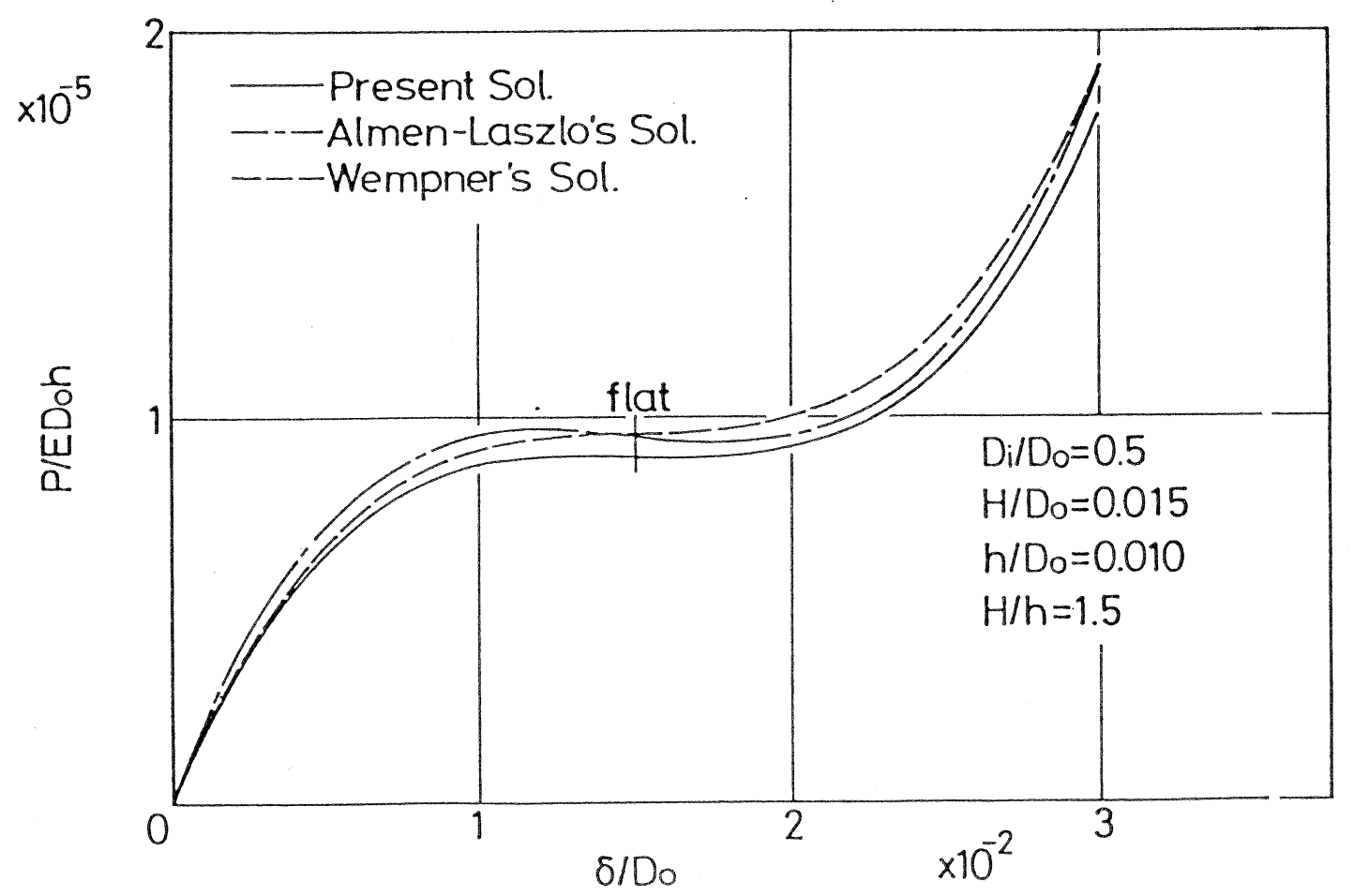

図 17. 荷重一たわみ線困（理論解）（7） 


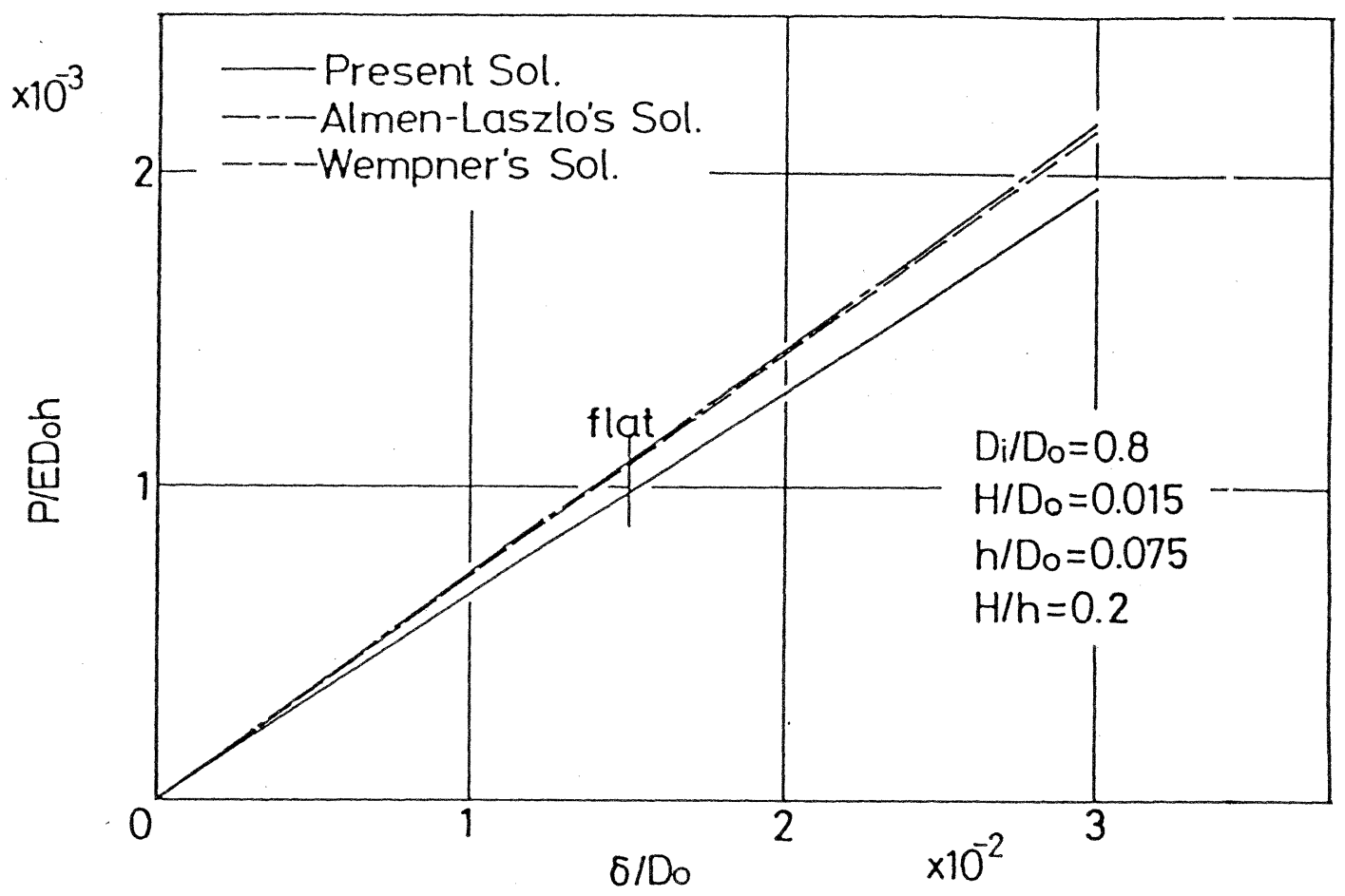

図 18. 荷重一たわみ線図（理論解）（8）

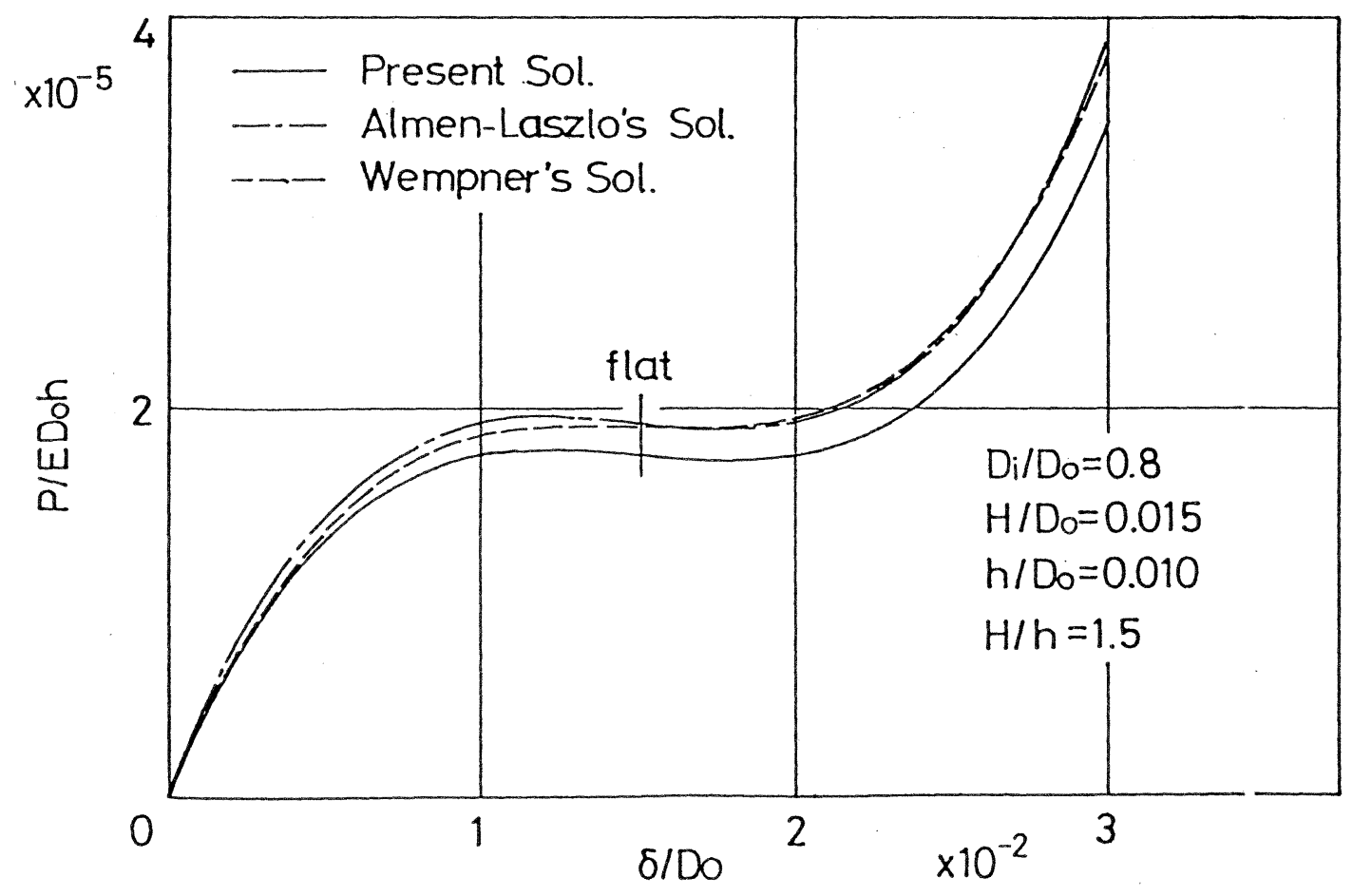

図 19. 荷重一たわみ線図（理論解）（9） 
図10にJIS 規格に規定されている皿ばねと，皿ばね 座金について，H/h と $\mathrm{D}_{\mathrm{i}} / \mathrm{D}_{\mathrm{o}}$ の值の分布を示した。こ の図上で, JIS 規格の寸法の分布を包含するように 9 個 の代表点(Sampling point)を設けて，これらの 9 個の $\mathrm{H} / \mathrm{h}$ と $\mathrm{D}_{\mathrm{i}} / \mathrm{D}_{\mathrm{o}}$ の組合せに対して三つの理論解による荷 重たわみ線図を求めた。その結果を図11～図19に示古。 ただし，H/Doの值には，すべて0.015の一定值を与え ている.

図11のパラメー夕値は，図10において 9 個の代表点 の中央に位置し，またJIS IIIL゙ね(軽荷重用)のパラメ 一夕值とほぼ同じであるために，これを基準として三 つの理論値を比較すると, 次のよ・うな傾向が認められ る。

(1) H/h が大きくなると (図15，図17，図19)，非線 形性が強くなり，またAlmen-Laszloの解と本 解との差が大きくなる。

(2) $\mathrm{H} / \mathrm{h}$ が小さくなると(図14, 図16, 図18)，非線 形性が弱くなり，またエネルギ法による二つの 解の差は小さくなる。

(3) $\mathrm{D}_{\mathrm{i}} / \mathrm{D}_{\mathrm{o}}$ が大きくなると(図13，図18，図19)，工ネ ルギ法による二つの解の差は小さくなり，また そられと本解との差は大きくなる。

(4) $\mathrm{D}_{\mathrm{i}} / \mathrm{D}_{\mathrm{o}}$ が小さくなると(図12, 図14，図15)， Wempnerの解と本解との差は小さくなる。

\section{5. あとがき}

皿ばねを設計する場合に，その荷重一たわみ線図を 正確に知ることが必要である。わが国では，従来より Almen-Laszlo の解が広く用いられてきたが,これは工 ネルギ法による近似解である。本論文では数多くの形 状に対して Almen-Laszlo の解法, Wempner の解法, および差分解法により荷重一たわみ線図を求めて比較 をしたので,これらの線困を通観すると, Almen-Laszlo の解の精度に関する，およその見当がつけられるであ ろう。

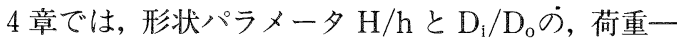
なわみ線図に及ぼす影響について四つの知見を得たが，

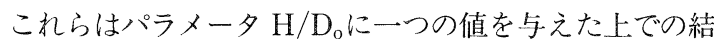
果であった.しかし 3 章で述べたように $\mathrm{H} / \mathrm{D}_{0}$ の值が多 少変っても，上記の四つの知見は大たい成立するもの と推論する。

筆者らとしては，血ばねの設計に際しては，Almen -Laszlo の解よりもWempnerの解の方を推奨したい, と考える。

なお，本研究の完了後に，下関，早坂 ${ }^{4)}$ が有限要素法 による二つの解析結果(一つは本報と同様に弾性解であ り, 他の一つは弾塑性解)を示していることを知った。 この報告では数值計算の䛊差の検討についての記述が ないが，その検討が十分になされておれば，弾性解に ついては本解法による結果と差がないはずである。上 述のように，本研究では数多くの計算例より，二つの エネルギ解の精度について知見を得たことに意義があ ると解して頂ければ幸である。

本研究では弾性薄款理論を用いたが，その大前提で ある, 款厚が二つの主曲率半径に比べて十分小さい, という条件は，多くの皿ばねの場合には満なされてい る。また内縁と外縁における殸端が子午線に垂直では なく中心軸に平行であり，これは殼理論における取扱 い方から外れているが，子午線に沿う血ばねの長さが 款厚に比べて十分大であれば，その影響は小さいもの と考えられる。

おわりに，本研究の実施にあたって，実験用の亚ば ね試験片について多大のご配虑を頂いた，平和発條株 式会社の岡田博文氏に対して, 深く感謝する。

\section{参 考 文 献}

1) Almen, J.O. and Laszlo, A., Trans. ASME, 58 (1936), p.305.

2) Wempner, G.A., Proc. 3rd U.S. Nat. Congr. Appl. Mech.(1958), p.473.

3 ）濱田，森田，播磨，森澤，日本機械学会論文集 (A)，53，487(昭62)，p.531.

4 ）下関，早坂，ばね技術研究会，昭和58年度秋期 講演会前刷集，p.41。 